\title{
Silent Resistance Against Androcentric Violence: An Ecofeminist Reading of Sarah Orne Jewett's "A White Heron"
}

\author{
Shreedhar Adhikari \\ Lecturer in English, Mahendra Campus, \\ Tribhuvan University, Nepalgunj, Nepal
}

This paper tries to unravel the cross-cutting dimensions of ecology and feminism for holistic analysis of "A White Heron." The theoretical insights drawn from both schools combine to form the critical lens of ecofeminism to find out the underpinning operational ideology and interpret literaty texts. Greta Gaard and Lori Gruen state: "Standing at the crossroads of environmentalism and feminism, ecofeminist theory is uniquely positioned to undertake a holistic analysis of these problems in both their human and natural contexts" (277). The evolution of interdisciplinary approach and critical practices has led to re-reading and reinterpreting the literary texts ever exploring and widening their dimensions.

Ecofeminism looks forward to establishing strong connection between environmental ills and women's suppression and both problems should be addressed together. It also pinpoints with the unique power and sensibility endowed to women by nature can create powerful force to resist the age long exploitation. Greta Gaard and Lori Gruen make it clear:

"Ecofeminism's central claim is that these problems stem from mutually reinforcing oppression of humans an of the natural world and of the natural world. It is no longer possible to discuss the environmental change without addressing the social change; and moreover, it is not possible to address women's oppression without addressing environmental degradation"(77).

It's through the blending of insights the crucial issues of women's suppression and nature's exploitation can end to create an organic unity between human beings and nature. The ecofeminist discourse ruptures the traditional hierarchical structure and posits women as protector of natural flora and fauna. Mary Grey explains:

It is the union of two concerns -ecology and justice for women. Ecology explores the interaction and interdependence of all life forms contained in the great web of life we call creation. It uncovers what promotes healthy interaction and what disrupts it-usually in the name of human greed (Grey,"Ecofeminism and Christian Theology", 481).

Ecofeminism, as a frame of reference, can be helpful tool to analyze Jewett's A White Heron to see the mutual connection and bonding between the protagonist Sylvia and all sorts of 
life forms she lives within the farm of New England. By resisting the male dominance silently she saves the life of a white heron and liberates herself from any patriarchal influences.

\section{Textual Analysis}

The narrative of Sarah Orne Jewett's"A White Heron" begins with the spatial attachment of Sylvia with nature while she was returning back to home with her companion Mistress Molly; amid the interplay of glimmering light and shadow in the woods of New England. Despite the approaching darkness of dusk Sylvia's bonding was so strong that she could walk easily and comfortably because she could trust her feet at such times. It was getting dark but she can walk with ease because "their feet were familiar with the path, and it was no matter whether their eyes could see it or not"(Jewett151). Her unity and integrity with nature is so intense that she is a companion to natural flora and fauna. Her life and happiness is connected to their life and happiness. In a sense she has symbiotic relationship with nature. Her existence depends on their existence and vice versa.

The protagonist Sylvia gives equal value to nature and all its inhabitants whether they are small insects, birds or large animals and regard them as her true companions. As she gets her true life after her arrival in New England, she feels it's this place where her true self merges in the mesmerizing natural beauty. She spends eight years of suffocating life in the crowded manufacturing town before arriving in this farm. She even feels sorry for the wretched life of geranium crammed in neighboring house. "It seemed as if she never had been alive at all before she came to life at the farm. She thought often with wistful compassion of a wretched geranium that belonged to a town neighbor"(Jewett152". She was afraid of folks in the crowded town, as her grandmother says, and needs a calm and serene environment of nature available in the countryside.

While moving homeward in the semidarkness of the evening with her companion Mistress Molly, Sylvia gets scared with unnatural whistling sound. She knows that it's not something that she is familiar with and it lacks the tone of "friendliness" too. She coils with fear when she is interrupted with the intruding sound." Not a bird's whistle which would have a sort of friendliness, but a boy's whistle, determined and somewhat aggressive"(Jewett152-53). The source of sound comes out as a tall young man with a gun on his shoulder: a hunter. $\mathrm{He}$ asks her name and favor for letting him spend the night at her house. She is extremely scared and nervous and maintains silence after giving her short introduction "Sylvy".

The hunter gets his bread and bed in a warm and hospitable manner. Such a welcome is quite natural in the countryside but rare in the towns and cities with urban dwellers. $\mathrm{He}$ introduces himself as an ornithologist and explains his passion of collecting birds since childhood. The anthropocentric hunter responds Mrs. Tilley's curiosity to what he does with collection," They are stuffed and preserved and dozens and dozens of them"(Jewett 154). Pursuing his whims and hobby, his present quest is a white heron. He has no any consideration to their roles and functions in the ecosystem. Driven by the self-centered whims he is least concerned with the idea of organic unity with nature. For him they are simply the objects of tests and experiments and perpetuate exploitation. Sylvia is sad to know that her "companions" 
are mere objects of experiment or means to satisfy the whims and hunger of ruthless hunter. The ideas of scientific theory during the enlightenment period replaced the previous belief of nature as living organism and accelerated the environmental destruction. Greta Gaard and Lori Gruen points out:

The works of Francis Bacon and Rene Descartes, nature was increasingly viewed as a machine which could be analyzed, experimented with, and understood through reason. This theory located animals in nature and authorized unlimited animal experimentation without anesthesia (Greta Gaard and Lori Gruen277).

Several species of birds, animals have been tortured and killed leading to their extinction. Human avarice and hubris particularly oppressive patriarchal ideology is detrimental behind environmental crisis.

As Sylvia lives close by nature she has the knowledge about all birds and animals living there, the hunter looks for Sylvia's favor in finding out the nest of the white heron. But she does not disclose any information she has. She lives by nature and the birds and animals are her companions. She can't be the agent of death to those creatures whom she loves most. Although she is attracted by the charming personality of hunter, she never likes idea of killing innocent birds."Sylvia would have vastly liked him vastly better without his gun; she could not understand why he killed the very birds he seemed to like so much"(Jewett155). Therefore she does not lead the hunter next morning when they go out to find the whereabouts of the white heron's nest. She simply follows him and maintains silence. He tries to tempt her with $\$ 10$ prize for the information but she silently resists both the exploitation of nature and exploitation of women.

His attempt to tempt the grandmother and granddaughter with money illustrates the commercialization and commoditization of nature. Putting price of $\$ 10$ as the value for bird reflects the patriarchal ideology of commoditizing both women's body and nature. However, she knows her responsibility to protect her integrity with nature. Paul W. Taylor argues:

From the perspective of a life-centered theory, we have prima facie moral obligations that are owed to wild plants and animals themselves as the members of Earth's biotic community. We are morally bound to protect or promote their good for their sake. Our duties to respect the integrity natural ecosystems, to preserve endangered species...(Taylor74)

This moral obligation seems not compatible with the oppressive male ideology which perceives both nature and women as objects of exploitation. Patricia Waugh states," Beliefs that legitimate the oppression of women also legitimate environmental degradation"(Waugh 538). Whereas women, as they live by nature, feel it their duty to safeguard nature. This close affinity of women with natural environment is the reason why women object the exploitation and take initiatives to protect nature and its integrity with their own life. 
Divided between the moral obligation to protect the environment and her fascination towards the hunter, Sylvia can't sleep the whole night. The second part of the story presents Sylvia's courageous spirit and "wild ambition" to go to the farther edge of the woods and climb the only remaining tallest pine tree and find out the whereabouts of the bird's nest:

Now she thought of the tree with a new excitement, for why, if one climbed it at break of the day could not see all the world, and easily discover from whence the white heron flew, and mark the place, and find the hidden nest (Jewet 155)?

Sylvia can only imagine the sort of delight her secret knowledge would entail in the morning. She decides to get out of the house before the young sportsman and his old mistress wake up. The desire for knowledge propels Sylvia to the direction of the woods at early dawn. She is no longer a timid girl even her age is only 9 at the time. She devises her own strategy to climb the huge tall pine tree:

First she mount the white oak tree that grew alongside, where she was almost lost among the dark branches and the green leaves heavy and wet with dew, a bird fluttered off its nest, and a red squirrel ran to and fro and scolded pettishly to the harmless housebreaker. Sylvia felt her way easily. She had often climbed there, and knew that higher still one of the oak's branches chafed against the pine trunk, just where its lower boughs were set close together (Jewett, 156).

Sylvia is both intelligent and courageous and knows what step to take in what situation. Without her tact and wisdom the climbing of such a tall tree would be impossible. As she is charged with the fire of compassion, she makes the impossible looking action possible. She feels that nature treats all living beings equally and the happiness lies in the organic unity with all the components of nature. She is guided by this consciousness and believes that each living beings have equal share to the resources of nature. The notion of coexistence and its practice can be traced in the life of Sylvia. For her all creatures aquatic and terrestrial are of equal importance to keep the ecological system in perfect balance.

After the perilous climbing into the pine tree, she finds herself on the top of it as a victorious. She can see all around from here including the secret abode of the white heron:

Now look down again, Sylvia, where the green marsh is set among the shining birches and dark hemlocks; there where you saw the white heron once you will see him again; look!, look! a white spot of him like a single floating feather comes up from the dead hemlock and grows larger, and rises, and comes close at last, and goes by the landmark pine with steady sweep of wing and outstretched slender neck and crested head. And wait! wait! do not move a foot or a finger, little girl, do not send an arrow of light and consciousness from you two eager 
eyes, for the heron has perched on a pine bough not far beyond yours, and cries back to his mate on the nest and plumes his feathers for the new day!

She sees the beautiful heron robed with white feathers from a close distance. She captures all the mesmerizing view from the tree top- the wide stretched sea, the marsh, the woods, the clouds, the birds of various species and on top of these she observes the majestic white heron fluming his feathers and welcoming the day. Such was the ecstatic sight of Sylvia. In a sense she was rewarded the beautiful sight for her audacity. She knows the secret truth about the elusive white heron. As possessing knowledge entails power, now Sylvia has the power whether to save the bird or reveal its secret to the hunter for the prize of ten dollar. Donovan admires Sylvia's decision to remain loyal to bird and nature:

In an earlier story, "A White Heron" (1886), Jewett had also dealt with the clash between women's loyalty to community versus the male will to destroy and isolate. In this story a young country girl, who is intimately familiar with her natural environment, is visited by a young man who hunts animals and birds for trophies. He realizes her knowledge and asks her to lead him to the bird that has succeeded in eluding him, a white heron. At first she is flattered, as she finds him romantically appealing, but in the end, though she knows exactly where the heron is, she keeps silent, refusing to betray her natural companion (Donovan, 375-376)

She descends the tree and returns home with her newly gained knowledge. "Although Sylvia discovers the nest of this rare bird, it is almost impossible that anyone else living in New England at the time could have accomplished such a feat" ( Joseph, 81).Both her grandmother and the sportsman expect the revelation but Sylvia doesn't speak at all. She must have weighed the pros and cons before shutting her mouth. No matter what prize is put for the life of the bird, she is determined not to disclose the truth. "No, she must keep silence"(Jewett157)! She resisted all the temptation through her silence. Her silence was so powerful that it made the gun laced hunter powerless. The temporary fascination towards the handsome hunter and his money fade at last with the deeper conscience to save the bird and nature. She can do this by maintain her powerful silence. Her silence resistance is symbolic. It is a nine year girl's resistance against the exploitation of nature and women. Such resistance also ruptures the traditional binary opposition that places women as secondary to male.

Man ruled and controlled for long enjoying the primary position under the traditional patriarchal construction of binaries:

Male/Female

Culture/Nature

Reason/Emotion

Mind/Body 
Such construction has assigned Man superior position and associated with all sorts of positive connotation whereas woman has been inferior and relegated with negative connotation. She has long been portrayed as the receiver of bread and butter from man. But the protagonist Sylvia ruptures the socially constructed boundaries. She is not only compassionate but a daring girl who climbs the tallest pine tree and gains power through it. As Orr posits her in a negotiating power:

Sarah Orne Jewett's "A White Heron" traces the transformation of an authoritatively mapped negotiation ( intiated by a young hunter toward a girl) into a negotiation of (different) equals: girl, heron, the larger natural world, writer, and even, potentially, male character and postmodern reader (Orr, 51).

She is in the position of the 'giver' and the hunter is in the position of 'receiver'. She has the full control over her decision whether to disseminate the knowledge or keep it secret. She opts the latter and disappoints the hope of male hunter. By doing this she achieves two things: ruptures the patriarchal hierarchy and asserts her power and identity; and saves the ecosystem by saving the life of the white heron.

\section{Conclusion}

A White Heron portrays Sylvia as a savior of nature. Young though she is, her moral choice surprises the readers at the end of the story. The hunter is presented as an infatuating agent doubled with his financial well being. His body and his money both are used to influence the girl and her grandmother to win the bird with their assistance. However, Sylvia silently resists all the temptation and strongly stands in favor of environmental protection. She doesn't let the bird die and perish at the hand of ruthless hunter. She defies the lucrative charms and firmly stands along with nature. For her neither money nor lust is more important than the integrity of nature. She doesn't betray her companion. The story asserts in the end that it's the women who can question and resist the traditional oppressive patriarchal discourse and save themselves and nature. By placing herself on top of the pine tree Sylvia challenging the traditional patriarchal order. She questions the validity of the old hierarchal notions that refuses to recognize the power and identity of women. Her silent resistance proves more powerful than the gun of the hunter. When the male hunter desperately asks about the whereabouts of the white heron, she simply keeps herself mute and resists both-patriarchal hegemony and exploitation of nature based on the hegemony. She establishes herself as a powerful girl who is strong enough to interrogate the prevailing male hegemony and place herself close to nature and save its treasures. Certainly, silence is woman's glory as Aristotle said. 


\section{Works Cited}

Donovan, Josephine. "A Woman's Vision of Transcendence: A New Interpretation of the Works of Sarah Orne Jewett." The Massachusetts Review, vol.21, no.2, 1980, pp.365380. JSTOR, www.jstor.org/stable/25089057.

Gaard, Greta and Lori Gruen." Ecofeminism:Toward Global Justice and Planetary Health." Environmental Ethics, edited by Light, Andrew, and Holmes Rolston III, Blackwell, 2003, pp.276-87.

Grey, Mary. "Ecofeminism and Christian Theology." The Furrow, vol.51, no. 9, 2000, pp481490. JSTOR, www.jstor.org/stable/27664137.

Jewett, Sarah Orne. A White Heron and Other Stories. Boston: Houghton, Mifflin and Company, 1886.

Joseph, Sheri. "Sarah Orne Jewett's White Heron: An Imported Metaphor." American Literary Realism, vol.27, no.3, 1995, pp.81-84.JSTOR, www.jstor.org/stable/27746628.

Orr, Elaine. "Reading Negotiation and Negotiated Reading: A practice with/in 'A White Heron' and 'The Revolt of Mother."' CEA Critic, vol,53, no.3,1991,pp.49-65. JSTOR,www.jstor.org/stable/44377067.

Taylor, Paul W. "The Ethics of Respect for Nature." Environmental Ethics, edited by Light, Andrew, and Holmes Rolston III, Blackwell, 2003, pp.74-84.

Waugh, Patricia. Ed. Literary Theory and Criticism. New York, OUP, 2006. 